\title{
Perplexity and Predicament: A Corpus Stylistic Analysis of A Summer Bird-Cage
}

\author{
Xuqin Lin \\ School of Foreign Studies \\ Anhui Normal University, Wuhu, China
}

Received: $1 / 4 / 2021$

Accepted: 2/7/2021

Published: $2 / 24 / 2021$

\begin{abstract}
This paper aims to explore the text style of Margaret Drabble's novel A Summer Bird-Cage. Specifically, it is intended to scrutinize how Drabble's language style vivifies her representation of some women characters' perplexity and predicament when they are confronted with problems related to value orientations and lifestyles. The present paper's significance lies in a methodological breakthrough and resultant interdisciplinary insights. To achieve the main aims specified above, this paper will explore the following research question: stylistically, how some lexical categories such as nouns, verbs, and clusters are related to the spatio-temporal order of the novel and to its discourse prosodies or "tone of characters" speeches. As a whole, this study is situated in a research context where previous and many current studies of A Summer Bird-Cage are primarily qualitative. To complement them, this paper embodies mixed methods research, featuring in a computer-aided, data-based, corpus stylistic approach to the style in Drabble's novel. Based on a multi-layered investigation of Drabble's language use and a close corpus stylistic analysis of it, this paper obtains some interesting findings as follows. First, some young, educated British women's complicated psychological experiences are thematized via narratorial introspection that centers around characters' processing of mind. Second, the tone of the women characters' speeches and the underlying attitude to some important issues are often negative, indicative of the women characters' bewilderment. In short, this paper adopts a corpus stylistic approach to thematic studies and character analysis as a contribution to the body of specialized knowledge of Drabble's art of fiction.
\end{abstract}

Keywords: A Summer Bird-Cage, Margaret Drabble, perplexity, predicament, stylistic analysis

Cite as: Lin, X. (2021). Perplexity and Predicament: A Corpus Stylistic Analysis of A Summer Bird-Cage. Arab World English Journal for Translation \& Literary Studies 5 (1)159-176.

DOI: http://dx.doi.org/10.24093/awejtls/vol5no1.11 


\section{Introduction}

Margaret Drabble is an important contemporary British woman writer who is often grouped with such internationally renowned novelists as A.S. Byatt and Angela Carter (Richetti et al, 1994, $\mathrm{p}$ 918). However, her works are much less studied than they deserve. To redress the situation, this paper is intended to closely analyse A Summer Bird-Cage and identify its stylistic features. 1960s witnessed a profusion of narrative fiction by women writers. In what respects is Drabble's novel distinguishable from her contemporaries' works? From the perspective of "narrative stylistics" (Simpson 2004: 18), this is a question worthy of an in-depth exploration. As an approach different from the existing ones, this paper, methodologically, applies corpus stylistics in narrative analysis, thus integrating qualitative and quantitative research with a view to more insightful findings.

A Summer Bird-Cage describes some well-educated women's psychological progress to self-actualisation through search for self-value and spiritual freedom in modern British society. To computationally identify and locate the stylistic features of Drabble's novel, this paper explores the stylistic features of the novel with the software of Wordsmith Tools 7.0 (Scott, 2016) and kfNgram (Fletcher, 2012) and discovers how the language presents the theme of the novel through the choice of language. The pronouns, nouns, and verbs are frequently deployed to present the characters' qualities, mental activities, and verbal communication. The three-word and four-word clusters will also be examined for detection of their functions in establishment of spatial and temporal relationships. As foci of critical attention, the following questions will be explored:

1) What are some salient stylistic features of Drabble's novel?

2) How do those features function to generate or accelerate narrative progression and enhance thematisation?

To find answers to the above questions in a corpus stylistic approach, this paper scrutinises the following aspects of the novel as its objects of studies:

(1) grammar and content words, such as pronouns, nouns and verbs as linguistic resources used to describe characters' attributes, mental activities and features of narrativization;

(2) three-word and four-word clusters embodying negation and indicating spatio-temporal orders respectively.

As this mixed methods research is empirical in orientation, it will generate new insights different from those yielded via traditional or exclusively interpretative methods.

\section{Literature Review}

Margaret Drabble's fiction spans almost five decades, devoting herself to portraying intellectual women's female consciousness in different life stages. 19 novels have been published consecutively so far since her first novel A Summer Bird-Cage came out in 1963. Her novels can be categorized into three groups. Group I includes semi-autobiographical novels with a strong realist flavor during the 1960s, focusing on the intellectual women's self-actualization and spiritual maturity. Group II comprises novels that reflect her vision of the social consciousness of middle- 
aged women from the 1970s to the 1980s. Group III embraces novels that were published since the middle of the 1980s, Drabble's novels have shifted from traditional realism to post-modernism, which are marked by a change in style from realist narrative representation to postmodernist one. (Wang, 2016, p. 10-30)

\section{Research context}

Studies of Drabble's novels have been undertaken from various angles of vision. They have been published in the forms of monographs and journal articles. Out of 47 publications, 31 of them are academic books or anthologies of contemporary literature, and Drabble is just mentioned as one of the contemporary writers or feminist writers without a detailed discussion of her novels. Five books are an introduction to a group of renowned feminist writers in history and Margaret Drabble is included as one of them. As these authoritative books comment, "Drabble's work displays a sense of the social concern which has been a strong characteristic of the English novel since the eighteenth century, but which is found in only a few writers today." (Carter \& Macrae, 2017, p. 467) Only 10 books are exclusively about Margaret Drabble's studies on her novels. Among these 10 books, four books are about Margaret Brabble's life experience and writing career while others focus on the different topics on the thematization, characterization, and intertextuality of Drabble's novels. At the same time, more than 100 papers in different journals have been published to analyze the thematization, female identity, a shift of writing style, characterization, narrative techniques, and so on. Before the 1980s these studies all agree that "of all the contemporary English women novelists, Margaret Drabble is the most ardent traditionalist." (Shawalter, 1977, p. 304)

After 2000, the study on Margaret Drabble's novels shifts from these literary features to a broader discussion. Among these books, three publications explore Drabble's novels more systematically in terms of feminist identity development, major themes, and style shift, such as Margaret Drabble's Novels: The Narrative of Identity (Singh, 2007), Female Intellectuals' Visions - A Thematic Study of Margaret Drabble's Three Novels(Yang, 2011), and From "Great Tradition" to "Postmodernism"- A Study of Margaret Drabble's Novels(Wang, 2016). Singh investigates Drabble's 16 novels from the perspective of feminism and discovers her unique narrative technique from fragmentation to wholeness. Yang Yuehua (2011) chooses Drabble's three novels to present female intellectuals' psychological change from the pursuit of independence and motherhood to women's social awareness in the trilogy of Drabble's three novels. Compared with this book, Wang Taohua (2016) delineates Drabble's writing style from traditional realism to modernism and postmodernism through her analysis of Drabble's seven representative short stories and novels in three stages. This book covers most of Margaret Drabble's novels and can be regarded as a milestone in studies of Margaret Drabble's studies because it has been a systematic analysis into Margaret Drabble's writing style so far.

But until now, no journal articles or monograph has applied a computer-assisted stylistic approach to her novels. Her language use has not been explored in a corpus-assisted 
methodological approach. Since a corpus stylistic approach embodies mixed methods research, it can be, theoretically, expected to yield more insights into the novel, thus hopefully making new contributions to the existing body of knowledge about Drabble's novels.

\section{Methodologies}

Stylistics as linguistically underpinned study of literary works

As specified previously, the present paper applies a corpus stylistic approach to Drabble's novel. As a sub-discipline of stylistics, corpus stylistics examines, computationally, how a given style is constituted. By definition, style is "the linguistic characteristics of a particular text" (Leech \& Short, 2007, p. 11), which is the object of stylistic studies. Stylistics is a discipline of studying language devices that are considered to create a literary style. "To do stylistics is to explore language, and more specifically, to explore creativity in language use." (Simpson, 2004, p. 3) The purpose of stylistics is to discover the relationship between language choices and aesthetic functions. Sometimes a writer departs from linguistic norms for an effect of defamiliarization, the concept of which was initially formulated by Shklovsky, a "poetic technique that forces readers to see the familiar things in strange and unfamiliar ways" (Pourjafari, 2012, p. 201). This produces a prominent psychological effect of foregrounding, coined by the Czech theorist Jan Mukarovsky. "In literature, foregrounding may be most readily identified with linguistic deviation: the violation of rules and conventions, by which a poet transcends the normal communicative resources of the language" (Childs \& Fowler, 2006, p. 90). Two techniques to create foregrounding are "repetition and parallelism" (Simpson, 2004, p. 50). "Foregrounding can be qualitative - deviation from the language code itself or quantitative - deviance from some expected frequency." (Leech \& Short, 2007, p. 39) Frequency is the repetition of words or structures repeated in a passage, so the arithmetic should be applied to do the counting.

Style is presented in the text through recurrence, pattern, and frequency, but how can it be measured? The style can "be measured in terms of deviations - either higher frequencies or lower frequencies - from the norm" (Leech \& Short, 2007, p. 35). The frequency can be revealed computationally and corpus stylistics utilizes software to find artistically motivated deviation or foregrounding statistically.

\section{Corpus stylistics}

Stylistics is considerably active and dynamic in the early 21 st century. There emerged cognitive stylistics, discourse stylistics, feminist stylistics, and corpus stylistics, and so on, as some core sub-disciplines of stylistics. Stylistics is based on theoretically informed, systematic, close linguistic analysis, while corpus stylistics "applies corpus methods to the analysis of literary texts, giving particular emphasis to the relationship between linguistic description and literary appreciation." (Mahlberg, 2014, p. 378) Using some software, corpus stylistics examines the relations between the frequency of patterned language items and their stylistic value. Therefore, the more frequent those patterns are, the greater significance they have. In other words, the recurrent features contribute more to the construction of meaning, generation, or maintenance of 
genre. The electronic data generated from the software is combined with the theoretically informed interpretation of language characteristics, integrating quantitative analysis and qualitative studies.

Since the 1980s, more and more researchers began to apply corpus stylistics in literary analysis. This interdisciplinary approach enables the provision of deeper insights into the literary texts. For example, in their seminal work, Semino and Short (2004) made a breakthrough in stylistic studies via enriching Leech and Short model by adding writing presentation and quantitative and qualitative analysis. Toolan (2009) combines corpus stylistics with narratology by delineating the matrix of eight parameters of narrative progression in short stories, which methodologically broadens the literary studies. Before 2010, these studies focused on the keyword techniques to literary analysis while after 2009 the scholars shifted their focus to clusters to disclose the linguistic features. Among the cluster analysis, Mahlberg (2013) especially pays attention to those related to body parts in Dicken's novels but Fischer-Starcke (2009) focuses more on the hierarchically analytical progression from word to text part to text in Austen's fiction to discover the characters' perception of the world.

\section{Multi-layered Analysis of A Summer Bird-Cage}

Of all the corpus analyses mentioned above, none of them was performed into A Summer Bird-Cage. In response, this paper applies a corpus stylistic approach to Drabble's novel. "All literary appreciation is comparative, as indeed is recognition of styles in general" (Widdowson, 1975, p. 84). Constructed in 1961, the Brown Corpus was contemporaneous with the corpus of $A$ Summer Bird-Cage (Drabble, 1963). Brown also contains narrative texts. In terms of genres included, therefore, Brown could serve as a rough and ready reference corpus. The tokens in $A$ Summer Bird-Cage are 67,700 and the Brown Corpus (from K to R) contains 297,902 tokens, which are almost five times that of A Summer Bird-Cage. Therefore, the Brown Corpus can serve as a reference corpus. Since the target novel is, in the main, narratively concerned with some women characters' processing of mind in their self-actualization, some keywords will be extracted using Wordsmith Tools. They will be analyzed with a view to the discovery of any meaningmaking patterns. Lemmas are in upper-case and word forms are in lower case, for instance, THINK includes thinks, thinking, and thought.

Besides Wordsmith Tools, the paper uses the software of kfNgram to generate 3-grams, which are most frequent in the novel. The kfNgram is a phraseological software that extracts "uninterrupted strings of words" (Fischer-Starcke, 2009, p. 31), n-grams, from a text or corpus. The dominant or frequent clusters are three-word and four-word clusters, and the two-word or fiveword clusters are inextracable in the analysis. Thus, this paper chooses the three-word and fourword clusters to discuss the language features and style of A Summer Bird-Cage. The following is an itemized, multi-levelled corpus stylistic analysis of the novel under discussion.

\section{Diction}

Arab World English Journal for Translation \& Literary Studies

ISSN: 2550-1542 | www.awej-tls.org 
Stylistics analysis consists of four categories: lexical categories, grammatical categories, figures of speech, and cohesion and context (Leech \& Short, 2007, p. 61). Owing to the limitation of space, this paper analyses linguistic items in lexical category, hoping to find out relations between the use of words as well as phrases and narrative style in Drabble's novel.

\section{Verbs}

According to Halliday \& Matthiessen (2014), language represents patterns of experience in the system of transitivity, which can be realized in the following six process types: material, behavioral, mental, verbal, relational, and existential. They subdivided the mental process (verbs) into four categories: "perceptive, cognitive, desiderative and emotive" ( pp. 214-257). In A Summer Bird-Cage, the mental verbs are frequently used, especially the cognitive verbs, which refer to perceptions or psychological states or activities of the fictional characters, instead of movements or physical acts, as the following table indicates.

Table 1. Frequency of mental verbs in the keywordlist

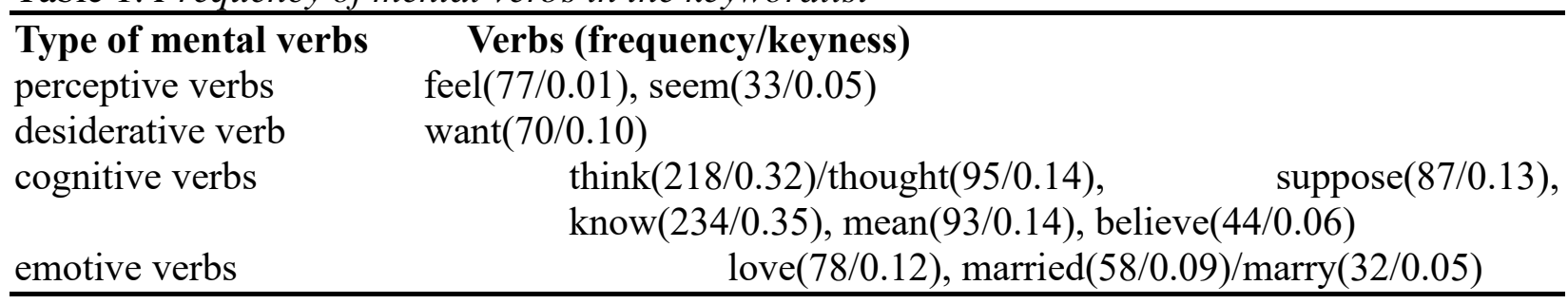

In the keywordlist of the first 100 words, cognitive verbs are overwhelmingly a major part of verbs, which are four verbs. 'Mental verbs, especially 'know', 'think', 'see', and 'mean', are particularly common in conversations. These verbs report states of awareness, certainty, perception, and desire" (Biber et al, 2002, p. 113). In A Summer Bird-Cage, there are numerous conversations. All the events happen between the heroine and her sister, her mother, and other friends, so the cognitive verbs illustrate the female characters' mental activity, unfolding the their understanding of the world. "The primary focus of A Summer Bird-Cage, however, is not the status within patriarchy of an educated young woman like Sarah, but her psychology" (Rose, 1980, p. 4). Besides, there is only one desiderative verb, want, whose low frequency also cause foregrounding of the female characters' weak inner desire. Take want as an example,

We could get married if we wanted. We

You won't want to stay with me,

I didn't want to talk female intimacies

I know who really wanted children

I don't know what I want to do

I feel like a still life. I want to do something

I didn't want to be Simone, or only at times

Arab World English Journal for Translation \& Literary Studies 


\section{Don't you want a proper career, Sarah?}

These conversations are pertinent to family, friends, employment, and marriage, which are common topics facing the girls about twenties. Most of them occur with negative expressions, such as didn't, won't and don't, which implies these women have a strong desire to free themselves from the social conventions, like encaged birds long for the freedom from the patriarchy. Particularly, if it is scrutinized in conversation, the context will further our perception of Sarah's view of career, as is shown in the next extract:

MAMA: Just any sort of job?

ME: Whatever there is.

MAMA: Don't you want a proper career, Sarah? I mean to say, with a degree like yours...

ME: No, not really, I don't know what I want to do. (p. 44)

The above extracted part is not conventional NRST(Narrative Report of Speech and Thought) in prose fiction because it is a dialogue of DS (Direct Speech) vividly presented in the format of play. Stylistically, it is formally "internal deviation", which stands out against the context of dialogic interaction. The author ingeniously uses "me" and the intimate salutation "mama" to create immediacy and shorten the distance between the author and the reader. Therefore, the reader is like sitting in a theatre and watching their vivid discussion of employment. Thematically, the interrogative sentence uttered by the mother with a pushing tone, clearly shows Sarah's mother is also a "New Woman" who values intellectual development of a girl and urges her daughter to think about the future path, indicating historical progress of feminist identity from a housewife in the first generation to a university-educated woman in the second generation.

\section{Nouns}

Nouns are used to refer to things, objects, persons, qualities, events, and so on. names things and persons by nouns. Things are classified into "abstract and concrete things" (Halliday \& Mattiessen, 2014, p. 58). In the keywordlist of A Summer Bird-Cage, the proper nouns of Louise, Stephen, Tony, Daphne, Gill, Francis, and John are listed, which shows the happening between Sarah and her sister and friends. Proper names of places are often mentioned at the same time because almost all of the characters are graduates from Oxford University, which indicates the characters are young intellectuals who are often concerned about marriage and love.

Table 2. Frequency of nouns in the keywordlist

\begin{tabular}{ll}
\hline Names of entities & Nouns \\
1. Proper names & Louise, Stephen, Tony, Sarah, Gill, Francis, Simone, London, \\
& Oxford, Paris, Rome
\end{tabular}

2. Common names:

persons

things, concrete, general

people, sister, Mama

Arab World English Journal for Translation \& Literary Studies

ISSN: 2550-1542 | www.awej-tls.org 
things, concrete, specific things, abstract wedding, invitation, taxi, party, dress, water writing, love

Perceivable from the above table, specific nouns outnumber general nouns. This can be attributed to the use of such nouns as invitation to present those narrative situations. As far as characterisation is concerned, this semantic preference throws some light on the dual nature of those women characters' daily life: easy, comforting, fancy on the one hand, but confining, challenging, conflicting on the other, thus implying thematically that they are, in a sense, encaged in marriage or family life. Moreover, the following three nouns are most frequent: wedding (34 occurrences), love (78 occurrences), and books (42 occurrences). Such frequency distributions show clearly those women characters' engagement, primary concern, and intellectual interest. Among others, love occurs most frequently, unmistakably indicating those characters' value orientation: genuine and gentle feeling is most important to those educated young women. At the same time, the frequent recurrence of the word books metonymically mirrors those women characters' active interest in reading, learning, and construction of knowledge: a hallmark of educated women's life. Also, it is inferable that, confined to books or, rather, propositional knowledge embodied in books, it is no wonder why those women found themselves perplexed when confronted with some problems in the real world.

The next recurrent noun wedding also marks off a turning point in her perception and cognition of a female's growth from girlhood to womanhood. The first paragraph of the novel validates the evolution from the perspective of the text world theory.

I HAD TO come home for my sister's wedding. Home is a house in Warwickshire, and where I was coming from was Paris. I was keen on Paris, but will refrain from launching into descriptions of the Seine. I would if I could, but I can't. I like the way things look, but can never remember them when I need to. So I'll leave Paris at that. I was leaving to go home to be a bridesmaid at the wedding of my sister Louise. ... either: all the foreignness that seemed so enchanting when I first went in July had begun to drive me to distraction. Every time somebody pinched me on the Métro I felt like screaming, and as for things like the lavatory paper and the price of chocolate and the brisk, bare-kneed, smart little girls... (p.1)

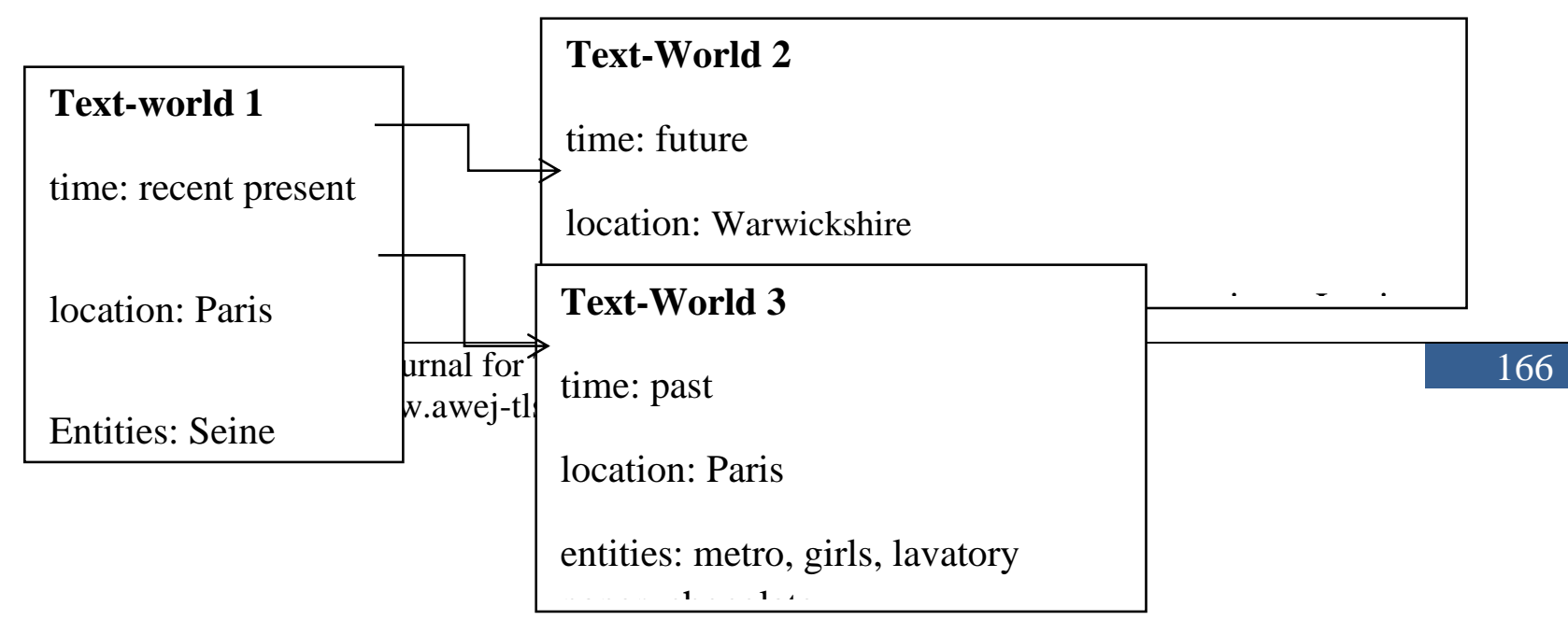




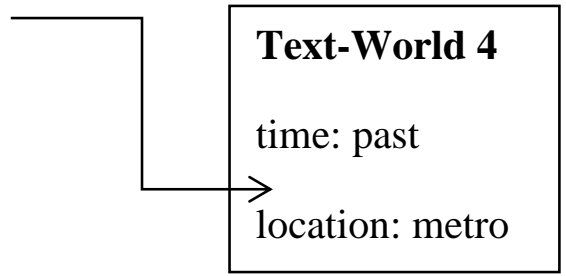

Figure 1. Text world analysis of the first paragraph in A Summer Bird-Cage

Perceptibly, it was written in past, present, and future tenses, creating different time frames. The text worlds shifting is advanced by some verbs, such as come, leave, and go. As Figure 1 shows, the first text world generates the other three text worlds, conveying to the reader that the story is situated at present, after two months in Paris and before the character's stay at home in the future. The integration of analepsis and prolepsis creates immediacy and impressiveness of decisionmaking at the beginning of the story as if the feeling is still conjuring up in the author's present mind, which is characteristic of the innovative modernist writing style. It is also a valid example of internal deviation against the context of the past tense in the story, creating the intersection between the past, the present, and the future. Furthermore, Sarah's attitudinal contradiction for Paris is manifested in the sentence: "I would if I could, but I can't" (p.1). Paris, metaphorically, is a symbol of romantic love, but Sarah decides to leave it, indicating that romantic flavor or love will fade gradually and lose its perpetual enchantment eventually. Conversely, home is the destination of the heroine's journey to attend a wedding, showing her awakening to the power or attraction of marriage or, by extension, family life.

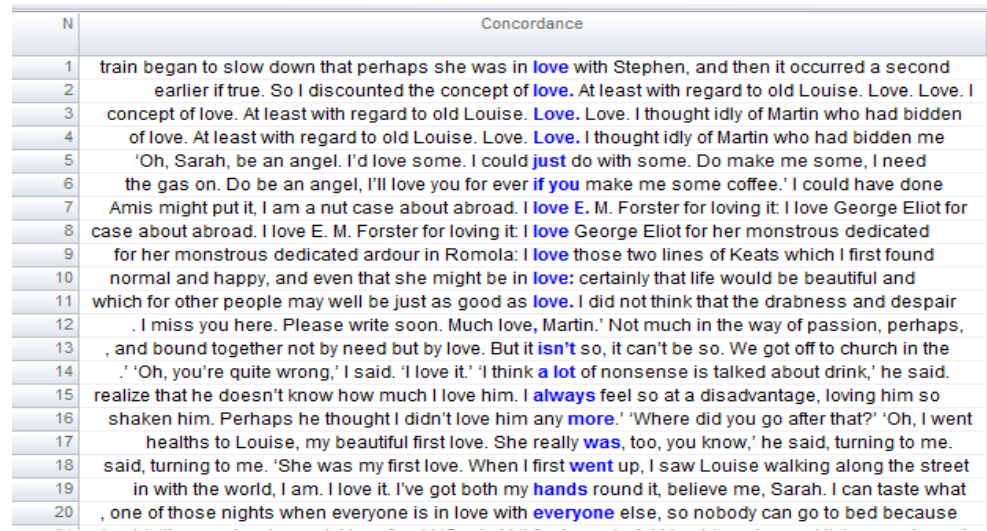

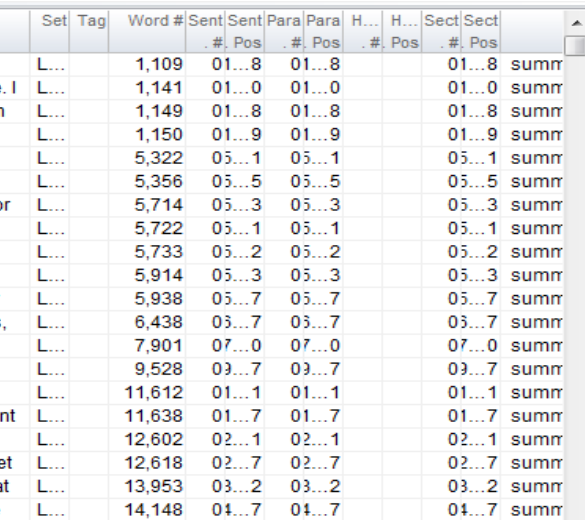

Figure 2. Concordance of the word love

Another prominent noun is love, which is disproportionately used in the novel because it is one of the major themes of the story. Among the 20 words, 17 words are about the emotive feeling for 
people and three words are about love for books of British classic literature, such as E. M. Forster, George Eliot, and John Keats as seen in the concordance lines 7, 8, and 9. These lines signify both the themes of love and her spiritual pursuit. Emphatically, in Concordance Line 2, Sarah contemplates Louise's marriage view. The mental process evolves from the initial confusion to the resultant need for a woman pursuing material wealth, so Sarah "discounted the concept of love" to claim her marriage view that marriage should not be based on material wealth. Stylistically, it paves the way for the potential marriage failure of Louise at the end of the story, thus flouting the reader's expectation of a happy marriage.

\section{Pronouns}

Performing a number of functions, pronouns can be divided into several categories: "personal pronouns, reflexive pronouns, demonstrative pronouns, and indefinite pronouns" (Biber et al., 2002, P. 92). Among all the personal pronouns, first-person pronouns are most frequently used, for example I, me and myself with respective frequencies of 3242, 645 and 104. The choice of the pronoun in A Summer Bird-Cage illustrates the overt first-person point of view and direct speech in the writing, deviant from the conventional third-person and male-dominated genres. By virtue of the character-focalizer I, the narrator Sarah's personal feelings and thoughts are directly presented. "When focalization lies with one character that participates in the fabula as an actor, we can refer to internal focalization" (Bal, 2017, p. 136). Besides, the origo $I$, as the zero reference point of subjectivity, features modernist writing because "twenty-first century humans have a strong notion of self and subjectivity"(Gavins, 2007). Finally, the preponderance of $I$ reveals that "at first her novels remain within the rubric of modernism by using the first person, and the protagonist can tell us about herself without violating modernist decorum" (Harper, 1982, p.157). Although most critics agree that she is a realist writer, as a novelist in the $20^{\text {th }}$ century, her writing usually applies the technique of "telling" rather than "showing", more modernist than realist.

\section{Hedges}

Paralleled with the above words, hedges are particularly preferred by the author and achieve high frequency.

Table 3 Frequency and keyness of hedges

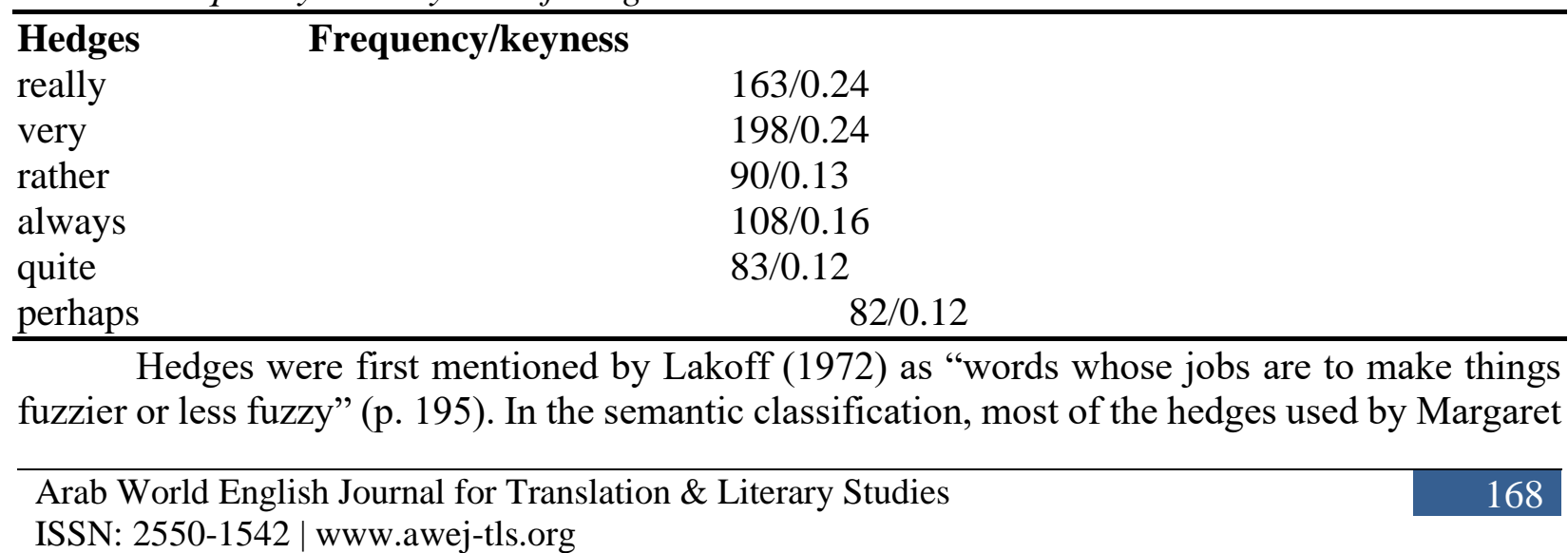


Drabble are hedges of degree rather than hedges of range of topic, quantity, or quality. The degree does not go to polarity or extremity, but mediates the conversation to avoid directness. Women's speech seems in general contained more instances of hedges which conveyed the sense that the speaker is uncertain about her statement or cannot vouch for its accuracy (Bucholtz, 2004, p. 79). Although she lacks empirical investigation of hedges, Lakoff "linked women's use of hedges with unassertiveness" (Coates, 2004, p. 88) because "asserting themselves strongly isn't nice or ladylike, or even feminine" (Bucholtz, 2004, p. 75). From the keywordlist of A Summer Bird-Cage, hedges are overwhelmingly used to disclose the characters' uncertainty, lack of confidence, and perplexity, compared with the reference Corpus (Only four hedges are found in the first 100 words in the wordlist ranking). This paper chooses concordance lines of really to analyze hedges.

Concordance Line13: Do I really?

Concordance Line 17: Did I really?

Concordance Line 39: Do you really want me to come?

Concordance Line 47: No, not really, I don't know what I want to do.

Concordance Line 53: I really don't know.

Concordance Line 54: I didn't really think so but I hadn't the nerve to suggest the other thing.

Concordance Line 13 is Sarah's uncertainty to her her appearance. Concordance Line 17 is also Sarah's uncertainty about Michael's affection and her accusation of that. Concordance Line 39 is Sarah's hesitation when she is asked whether to go out with her sister Louise and Stephen, which reveals Sarah's indeterminacy to be involved with a couple, a marital relationship. Concordance Line 47 and 53 demonstrate the psychological status of Sarah's friend Gill, who is married and jobless. When asked about what to do in the future, Gill does not know whether to work outside the home or what to do. From the above concordance lines, really is not used to emphasize the facts, but mitigate the force of utterances and show the speakers' tentativeness or even negative evaluation, thus truth value is reduced. When arriving at adulthood, women are confronted with the choice between marriage and occupation. In A Summer Bird-Cage, Sarah finds that her jobless friends and her sister are involved in a unhappy marriage, which sets her into meditation: what is the relationship between marriage and job? Why should women get married? She is haunted by the perplexity from the beginning to the end of the novel.

\section{Clusters}

Clusters have been studied by many researchers and endowed with different terms and interpretations. Scott (1997) at first call these formulaic expressions as "clusters". Altenberg (1998) defines "recurrent word-combinations" as "any continuous string of words occurring more than once in identical form"(p. 195). Biber et al. (2002) call them "lexical bundles". Stubbs \& Barth (2003) call them "chains" (p.61). "Uninterrupted chains of $n$ words are called n-grams" (Fischer-Starcke, 2009, p. 108). Sinclair (2008) asserts that "the normal primary carrier of meaning is the phrase and not the word; the word is the limiting case of the phrase and has no other status in the description of meaning" (p. 409). Therefore, this paper applies "cluster" in Wordsmith Tools 
and analyze the implied meaning of the most frequent three-word and four-word grams. The following tables clarify the reasons why three- and four-word grams are prominent in the text, compared with the Brown Corpus.

Table 4 Frequency and percentage of n-gram in A Summer Bird-Cage

\begin{tabular}{lrrccc}
\hline Length & 3-word & 4-word & 5-word & 6-word & \\
Frequency & & 1,682 & 307 & 59 & 9 \\
Percentage & $81.8 \%$ & $14.9 \%$ & $2.9 \%$ & $0.4 \%$ & \\
\hline
\end{tabular}

Table 5 Frequency and percentage of $n$-gram in the Brown Corpus

\begin{tabular}{lrrrrr}
\hline Length & 3-word & 4-word & 5-word & 6-word \\
Frequency & & 6,135 & 1,666 & 138 & 150 \\
Percentage & $75.8 \%$ & $20.6 \%$ & $1.7 \%$ & $1.9 \%$ & \\
\hline
\end{tabular}

From the above table, it is self-evident that 3-grams and 5-grams in A Summer Bird-Cage are more frequent than those of the Brown Corpus. The number of 3-grams and 4-grams is much more than the other types of grams, so the most frequent 3-word and 4-word grams are extracted and analyzed. Six-word clusters occupy only a small part and can be ignored.

\section{Clusters describing spatial and temporal relations}

Table 6 Three -word and four-word clusters in A Summer Bird-Cage

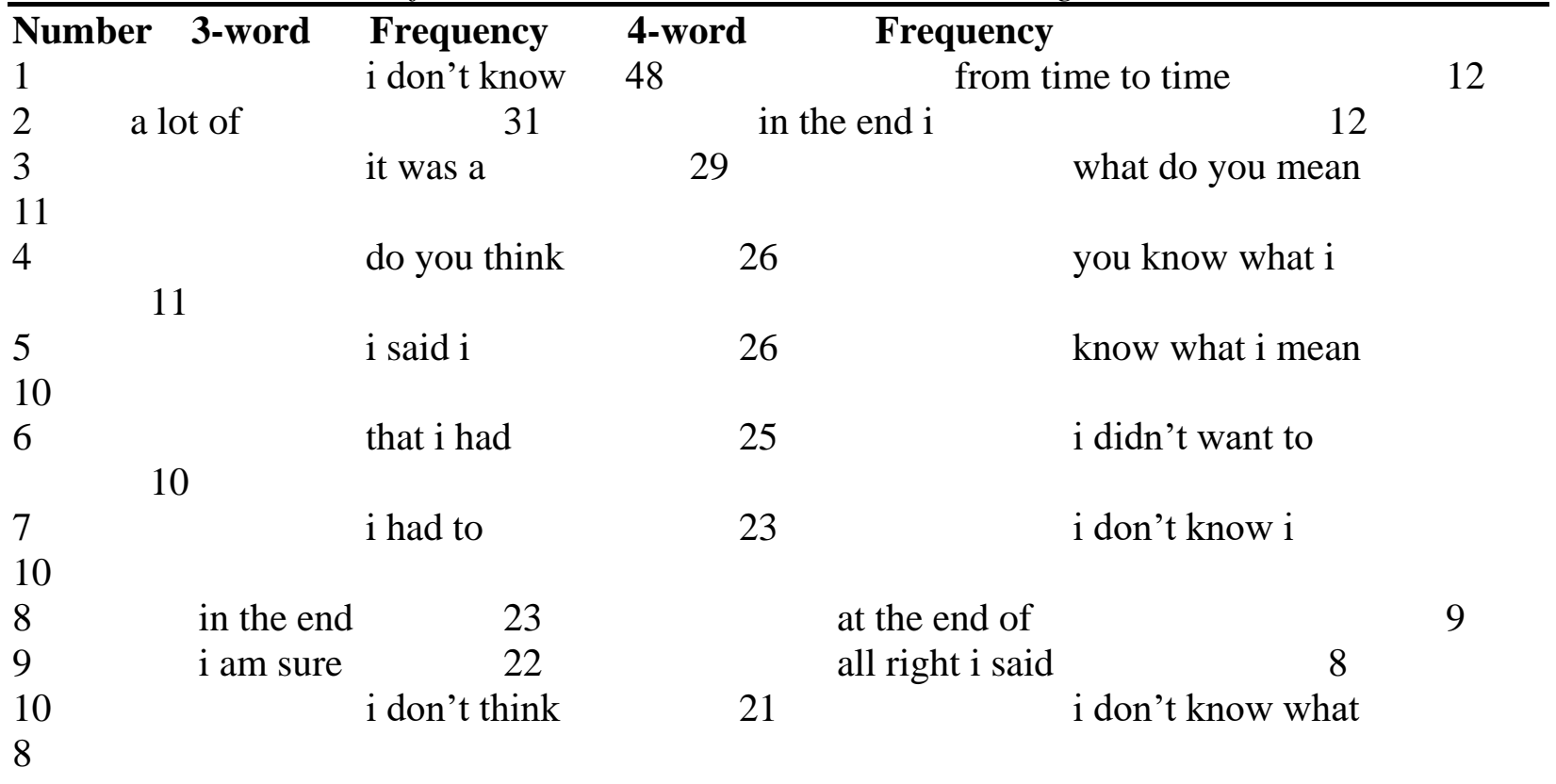


AWEJ for Translation \& Literary Studies Volume, 5 Number 1. February 2021

Perplexity and Predicament: A Corpus Stylistic Analysis of A Summer Bird-Cage

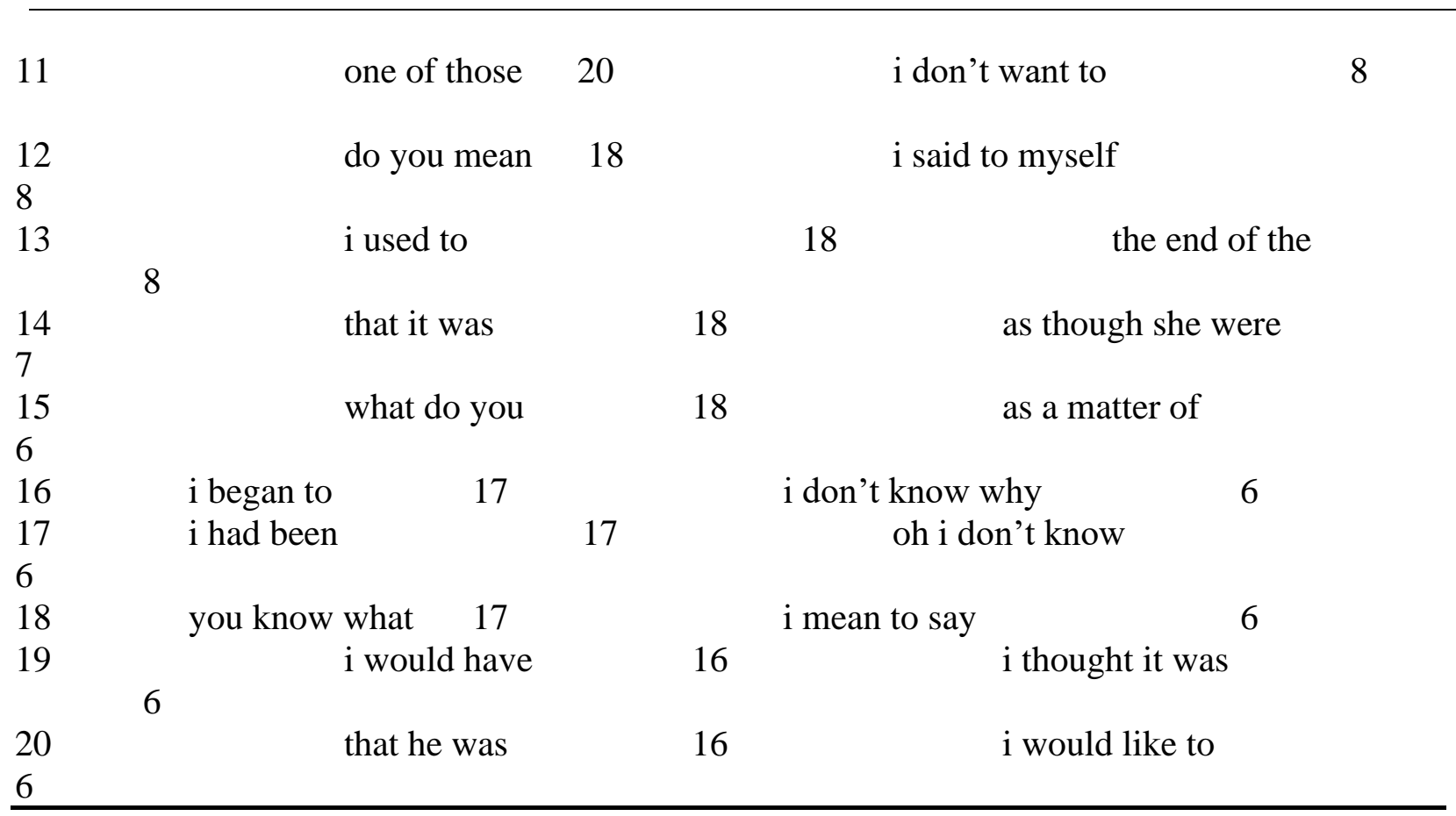

Table 7. Patterns of 3-grams and 4-grams

\begin{tabular}{|c|c|c|c|}
\hline & 3-grams & 4-grams & \\
\hline $\begin{array}{l}\text { 1. Temporal, spatial, quantitative, qualitative } \\
\text { relationships }\end{array}$ & 4 & & 5 \\
\hline 2. Containing pronouns (including 'I') & $14(10)$ & & $16(14)$ \\
\hline $\begin{array}{l}\text { 3. Including a verb, adjective, or noun } \\
\text { describing a mental process }\end{array}$ & & & 11 \\
\hline 4. Including the grammatical negation 'not' & 2 & & 6 \\
\hline $\begin{array}{l}\text { 5. Having question words } \\
1\end{array}$ & & 3 & \\
\hline
\end{tabular}

In the above Table 6, the first 20 three-word and four-word clusters are extracted. Table 7 is extracted from Table 6 of three-grams and four-grams. According to the lexical characteristics, this paper classifies the grams into five groups. From Table 7, the preponderance of clusters is related to the pronoun $I$ and most of them collocate with the mental verbs: think and know, indicating the characters' frequent mental activities.

In the 4-grams, *the end* includes the three phrases: in the end $i$, at the end of, and the end of the. In the end $i$ mirrors the heroine's activity and usually appears at the beginning of a sentence. The variant slot fillers indicate the narrative closure of an event and also the beginning 
of another event, which pushes the development of narration. But in the end is "a circumstance adverbial of point in time"(Biber et al., 2002, pp. 362). For example,

Thinking how unfair it was, to be born with so little defense, like a soft snail without a shell. Men are all right, they are defined and enclosed, but we in order to live must be open and raw to all comers. What happens otherwise is worse than what happens normally, the embroidery and the children and the sagging mind. I felt doomed to defeat. I felt all women were doomed. Louise thought she wasn't but she was. It would get her in the end,(p. 15)

This extract is Sarah's deep thinking about the inequality between men and women. Metaphorically, women are vulnerable and defenseless because she compares women to "a soft snail without a shell". Furthermore, the juxtaposition of "the embroidery and the children and the sagging mind" is not common since there is no comma between the last two nouns, which shows the nonstop and natural narration of destined failure for women. In this example, in the end has the final position in the sentence to indicate the consequence, but sometimes in the end is placed in the initial position to "introduce a new scenario" ( Biber et al., 2002, pp. 371), for example, "In the end I got a job with the BBC". In the end marks the spaial-temporal transition from Sarah's home to London, which is narratorial shifting from Louise's marriage to Gill's marriage.

\section{Syntactic Negation}

Nine of the first 203 -word and 4-word clusters begin with the first-person pronoun "I", which centralize the role or position of the heroine. Besides, the sentence structure of "Subject + Negative word + Verb" or syntactic negation is salient. Syntactic negation is principally realized by the negative particle not and its contracted form $n$ 't. These are seen as prototypical forms of negation (Jeffries \& McIntyre, 2010, p. 94). The list of 4-word grams even contains six negative clusters: $i$ didn't want to, $i$ don't know $i$, i don't know what, $i$ don't want to, $i$ don't know why, and oh $i$ don't know. Evidently, the negative words are mostly combined with the cognitive verbs think and know, which reflect the characters' mental activities. In the rank of 3-word clusters, two negative clusters are foregrounded and $i$ don't know is the most frequent. Therefore, this paper chooses $i$ don't know to explore the mental process embedded in the collocation.

The following concordance lines can provide rich materials for the analysis. Among the 48 concordance lines of $i$ don't know, 35 sentences are said by the heroine Sarah, nine sentences by Sarah's sister Louise and five by Sarah's friend Gill. As for the topic, 21 lines are about love and marriage, 31 lines about women's job. Almost all of them are in quotation marks, which are a marker of direct speech for direct thought presentation. In their conversation, there are almost no report words, such as said, to indicate the interlocutors, as if the reader is watching a TV play without interruption of the narrator. Therefore, the dominant use of DS(Direct Speech) vividly and directly presents the scene and characters, a realist writing style.

Arab World English Journal for Translation \& Literary Studies 
Concordance line 5: “Oh, I don't know. Surely one would feel like a lamb led to the slaughter and all that?"

Concordance line 6: “Oh, I don't know." I couldn't go into the twisted motives of middle-class girls with no sense of vocation, although I felt I was becoming an expert on the subject.

Concordance line 7 and 8: “Oh, I don't know what to say about it really...I don't know how it happened."

Concordance line 15: "No, not really, I don't know what I want to do."

Concordance line 16: “I don't know what I wouldn't have given for the opportunities you've been given."

Concordance line 23 and 24: "I don't know," I said. "I don't know at all."

Concordance line 43: "I don't know, I really don't."

Concordance line 48: She says she has learned her lesson, but I don't know what she means by that.

From the above concordance lines, $i$ don't know is said by different people: Sarah, Louise, and Gill. The frequent occurrence of the phrase hints at the negative narratorial tone of the three major characters in the predicament of their life. Concordance line 5 is the conversation between Sarah and Louise just the night before Louise's wedding. Sarah compares a bride to a lamb which is led to the slaughter, which reveals Sarah's fear or hatred towards marriage and the female helplessness in marriage. Concordance line 7 and 8 are about the marital condition of Gill, who gets married immediately after she graduates from Oxford and divorces afterwards. Gill and Louise represent two extremes of marriage: one is for money and another without a vocation. What is a perfect marriage? Should women have jobs after marriage? I don't know perpetualize these issues in the characters' minds and foreground the confusion of the theme in the readers' minds, which is a prominent feature of modernist writing.

Superficially, the female characters get married and jobless, which inflicts a conflict between marriage and occupation, but there is no logic between them. Margaret Drabble's early work was in line with the second wave of feminism, salient in self-referentiality and feminism. She once stated that the last book she read in Cambridge influenced her profoundly: Simone De Beauvoir's The Second Sex, which was "material that nobody had used and I could use and nobody had ever used as far as I would use it" (Firchow, 1974, pp. 102-121) The perplexity is not the confusion about whether a girl should take a job or get married, but a young girl's predicament when she experiences from a girl to a woman: "how and on whose terms to enter the adult world" (Rose, 1988 , p. 3). I don't know is repeated by the different female characters when they are confronted with employment, love, marriage, and divorce, which reflects women's perplexity in their social predicament. The dominantly negative tone permeates the novel.

\section{Conclusion}

The present paper examines the themes and character portrayal in Drabble's A Summer Bird-Cage through detailed corpus stylistic analysis into a good number of lexical categories and 
clusters. The corpus-assisted investigation demonstrates the linguistic features of the novel have enhanced the effectiveness of thematization and characterization in the story. The overwhelmingly negative tone of characters' speeches felicitously embodies the three female characters' perplexity and predicament in their critical life stage.

Further research on Drabble's novels could be enriched with more extended scope to cover most of her novels and investigate the phased features of her writing. What's more, the software can be applied more proficiently and the analysis can be more thorough through the comparison of a self-made corpus of Drabble's five early novels from 1963-1969 or the five novels of her contemporaries for more findings about Drabble's individualized narrative style. Finally, relevant theories and methods can be incorporated into the research in order to obtain more interdisciplinary findings regarding Drabble's art of fiction, such as speech act theory, schema theory and conversation analysis.

\section{About the Author:}

Xuqin Lin is a lecturer teaching English for more than twenty years in China. She graduated from Anhui Normal University, China and got her master's degree in 2008 with a concentration in British and American literature. Her academic interests are corpus stylistics, second language acquisition, and edusemiotics. ORCID ID: https://orcid.org/0000-0002-8386-4191

\section{Acknowledgment}

I express my heartfelt gratitude to Professor Jian Luo in Anhui Normal University, China for his systematic introduction to stylistics and his insightful advice and continued help in my study.

\section{References}

Altenberg, B. (1998). On the phraseology of spoken English: The evidence of recurrent wordcombinations. In A.P. Cowie (ed.), Phraseology. Theory, Analysis, and Applications. Oxford: Oxford University Press, 101-122.

Bal, M. (2017). Narratology: Introduction to the Theory of Narrative. Toronto: University of Toronto Press.

Biber, D., Conrad, S., \& Leech, G. (2002). Longman Student Grammar of Spoken and Written English. London: Longman.

Drabble, M. (2013). A Summer Bird-Cage. Boston and New York: First Houghton Mifflin Harcourt.

Bucholtz, M. (2004). Language and Woman's Place: Text and Commentaries. Oxford: Oxford University Press.

Carter, R. \& Macrae, J. (2017). The Routledge History of Literature in English: Britain and Ireland (3rd ed.). London and New York: Routledge.

Childs, P., \& Fowler, R. (2006). The Routledge Dictionary of Literary Terms. London \& New York: Routledge.

Coates, J. (2004). Women, Men and Language. London \& New York: Routledge. 
Firchow, P. (1974). Interview with Margaret Drabble. In P. Firchow, (ed.), The Writer's Place: Interviews on the Literary Situation in Contemporary Britain (pp. 50-62). Minneapolis: University of Minnesota Press.

Fischer-Starcke, B. (2010). Corpus Linguistics in Literary Analysis: Jane Austen and her Contemporaries. London: Continuum.

Fletcher, W. H. (2012). kfNgram. Annapolis, MD: USNA. Retrieved from https://www.kwicfinder.com/kfNgram/kfNgramHelp.html

Gavins, J. (2007). Text World Theory: An Introduction. Edinburgh: Edinburgh University Press.

Halliday, M.A.K. \& Matthiessen, C. M. I. M. (2014). Halliday's Introduction to Functional Grammar. London \& New York: Routledge.

Harper, M. (1982). Margaret Drabble and the Resurrection of the English Novel, Contemporary Literature, 23( 2 ) pp. 145-168.

Jeffries, L., \& McIntyre, D. (2010). Stylistics. Cambridge: Cambridge University Press.

Lakoff, G. (1972). Hedges: a Study in Meaning Criteria and the Logic of Fuzzy Concepts, In Papers from the Eighth Regional Meeting of Chicago Linguistic Society. Chicago: Chicago University Press.

Leech, G. Y., \& Short, M. (2007). Style in Fiction. London: Longman.

Mahlberg, M. (2013). Corpus Stylistics and Dickens's Fiction. London: Routledge.

Mahlberg, M. (2014). Corpus Stylisitics. In Michael Burk(eds.), The Routledge Handbook of Stylistics (pp. 378). London \& New York: Routledge.

Pourjafari, F. (2012). Defamiliarization in Sohrab Sepehri's Poetry, Canadian Social Science, 8(1), 200-203.

Richetti, J., Bender, J., David, D., and Seidel, Michael. (1994). The Columbia History of the British Novel(eds.). New York: Columbia University Press.

Rose, E.C. (1980). The Novels of Margaret Drabble : Equivocal Figures. London: Macmillan.

Rose, E. C. (1988). The Sexual Politics of Narration: Margaret Drabble's Feminist Fiction, Studies in the Novel, 20 (1), 86-99.

Scott, M. (2016). WordSmith Tools version 7.0. Stroud: Lexical Analysis Software.

Semino, E. \& Short, M. (2004) Corpus Stylistics: Speech, Writing and Thought. Presentation in a Corpus of English Writing. London: Routledge.

Showalter. E. (1977). A Literature of Their Own: British Women Novelists from Bronte to Lessing. Princeton: Princeton Unversity Press.

Simpson, P. (2004). Stylistics: A Resource Book for Students. London \& New York: Routledge.

Sinclair, J. McH. (2008). The phrase, the whole phrase, and nothing but the phrase. In S. Granger and F. Meunier (eds.), Phraseology: An Interdisciplinary Perspective (pp. 407-410). Amsterdam: John Benjamins.

Singh, A. (2007) Margaret Drabble's Novels: The Narrative of Identity. Delhi: Academic Excellence.

Arab World English Journal for Translation \& Literary Studies 
AWEJ for Translation \& Literary Studies Volume, 5 Number 1. February 2021

Perplexity and Predicament: A Corpus Stylistic Analysis of A Summer Bird-Cage

Stubbs, M \& Barths, I. (2003). Using Recurrent Phrases as Text-type Discriminators. Functions of Language, 10(1): 65-108 .

Toolan, M. (2009). Narrative Progression in the Short Story: A Corpus Stylistic Approach. Amsterdam/Philadelphia: John Benjamins

Wang, T. H. (2016). From "Great Tradition" to "Postmodernism"-A Study of Margaret Drabble's Fiction. Changsha: Hunan People's Press.

Widdowson, H. (1975). Stylistics and the Teaching of Literature. London \& New York: Routledge.

Yang, Y. H. (2011). Female Intellectuals Visions-A Thematic Study of Margaret Drabble's Three Novels. Chengdu: Sichuan Publishing House.

Arab World English Journal for Translation \& Literary Studies

ISSN: 2550-1542 | www.awej-tls.org 